\title{
Front Matter: Volume 9200
}

, "Front Matter: Volume 9200," Proc. SPIE 9200, Photonic Fiber and Crystal Devices: Advances in Materials and Innovations in Device Applications VIII, 920001 (30 September 2014); doi: 10.1117/12.2084663

EDIE Event: SPIE Optical Engineering + Applications, 2014, San Diego, California, SPIE. United States 


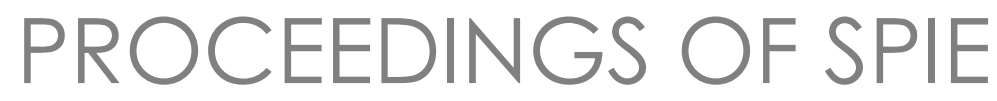

\title{
Photonic Fiber and Crystal Devices: Advances in Materials and Innovations in Device Applications VIII
}

\author{
Shizhuo Yin \\ Ruyan Guo \\ Editors
}

17-18 August 2014

San Diego, California, United States

Sponsored and Published by

SPIE 
The papers included in this volume were part of the technical conference cited on the cover and title page. Papers were selected and subject to review by the editors and conference program committee. Some conference presentations may not be available for publication. The papers published in these proceedings reflect the work and thoughts of the authors and are published herein as submitted. The publisher is not responsible for the validity of the information or for any outcomes resulting from reliance thereon.

Please use the following format to cite material from this book:

Author(s), "Title of Paper," in Photonic Fiber and Crystal Devices: Advances in Materials and Innovations in Device Applications VIII, edited by Shizhuo Yin, Ruyan Guo, Proceedings of SPIE Vol. 9200 (SPIE, Bellingham, WA, 2014) Article CID Number.

ISSN: 0277-786X

ISBN: 9781628412277

Published by

SPIE

P.O. Box 10, Bellingham, Washington 98227-0010 USA

Telephone +1 3606763290 (Pacific Time) · Fax +1 3606471445

SPIE.org

Copyright @ 2014, Society of Photo-Optical Instrumentation Engineers.

Copying of material in this book for internal or personal use, or for the internal or personal use of specific clients, beyond the fair use provisions granted by the U.S. Copyright Law is authorized by SPIE subject to payment of copying fees. The Transactional Reporting Service base fee for this volume is $\$ 18.00$ per article (or portion thereof), which should be paid directly to the Copyright Clearance Center (CCC), 222 Rosewood Drive, Danvers, MA 01923. Payment may also be made electronically through CCC Online at copyright.com. Other copying for republication, resale, advertising or promotion, or any form of systematic or multiple reproduction of any material in this book is prohibited except with permission in writing from the publisher. The CCC fee code is 0277-786X/14/\$18.00.

Printed in the United States of America.

Publication of record for individual papers is online in the SPIE Digital Library.

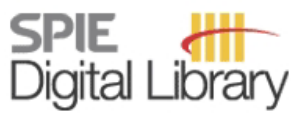

SPIEDigitalLibrary.org

Paper Numbering: Proceedings of SPIE follow an e-First publication model, with papers published first online and then in print and on CD-ROM. Papers are published as they are submitted and meet publication criteria. A unique, consistent, permanent citation identifier (CID) number is assigned to each article at the time of the first publication. Utilization of CIDs allows articles to be fully citable as soon as they are published online, and connects the same identifier to all online, print, and electronic versions of the publication. SPIE uses a six-digit CID article numbering system in which:

- The first four digits correspond to the SPIE volume number.

- The last two digits indicate publication order within the volume using a Base 36 numbering

system employing both numerals and letters. These two-number sets start with 00, 01, 02, 03, 04, 05, 06, 07, 08, 09, 0A, 0B ... 0Z, followed by 10-1Z, 20-2Z, etc.

The CID Number appears on each page of the manuscript. The complete citation is used on the first page, and an abbreviated version on subsequent pages. Numbers in the index correspond to the last two digits of the six-digit CID Number. 


\title{
Contents
}

\author{
vii Authors \\ ix Conference Committee
}

\section{SESSION 1 ADVANCES IN PHOTONIC CRYSTALS AND MATERIALS I}

920003 Elaborations on surface structural effects and optical waveguide properties of gadolinium oxide $\left(\mathrm{Gd}_{2} \mathrm{O}_{3}\right)$ and gadolinium oxide europium doped $\left(\mathrm{Gd}_{2} \mathrm{O}_{3}: \mathrm{Eu}^{3+}\right)$ sol-gel films [9200-2]

920004 Helical auto-waves of electron-hole plasma in semiconductor induced by femtosecond pulse at presence of external electric field [9200-3]

920006 Formation of sub pico-liter liquid periodic structure in a hollow optical fiber for photonic device applications [9200-5]

920009 A compact in-situ ellipsometer using the liquid crystal variable retarder [9200-8]

9200 0A Optical characterization of ferroelectric PZT thin films by variable angle spectroscopic ellipsometry [9200-9]

\section{SESSION 2 ADVANCES IN PHOTONIC CRYSTALS AND MATERIALS II}

9200 OC Efficient upconversion polymer-inorganic nanocomposite thin film emitters prepared by the double beam matrix assisted pulsed laser evaporation (DB-MAPLE) (Invited Paper) [9200-10]

9200 OD Self-pulsing in a large mode area, end-pumped, double-clad ytterbium-doped fiber laser [9200-11]

9200 OE Beam shaping for holographic techniques [9200-12]

$9200 \mathrm{OH}$ Design and analysis of large-mode-area microstructured polymer optical fibre with singlemode operation [9200-17]

9200 0l Study of characteristics of MMI devices using matrix approach [9200-18]

\section{SESSION 3 INNOVATIONS IN DEVICES AND APPLICATIONS I}

9200 OK Application of quantum dots in solid state lighting [9200-20]

$9200 \mathrm{OL} \quad$ Numerical analysis for a solid-core photonic crystal fiber with tunable zero dispersion wavelengths [9200-21] 
9200 ON Three-dimensional display based on volume holographic kinoform in photopolymer (Invited Paper) [9200-23]

920000 Tunable spectrum LED based on micro/nanostructured substrate [9200-56]

9200 0Q Photonic crystal based nano-displacement sensor [9200-25]

SESSION 4 INNOVATIONS IN DEVICES AND APPLICATIONS II

9200 OS 2-10 $\mu \mathrm{m}$ supercontinuum broadening using a highly nonlinear chalcogenide microfiber for mid-IR applications (Invited Paper) [9200-27]

9200 OU Mid-IR supercontinuum generation and applications: a review [9200-29]

9200 OV Gain dynamics in liquid crystal photorefractive hybrids [9200-30]

$9200 \mathrm{OW}$ The calculation of the coherence time of spectral supercontinuum at the output of the fused silica with different parameters of the initial pulse [9200-31]

9200 0X Super broadband ultrafast waveguide switches based on dynamic waveguiding effect [9200-32]

$9200 \mathrm{OZ}$ Phase-shifting holography using Bragg and non-Bragg orders in photorefractive lithium niobate [9200-34]

920010 Single-plafform Si photonic components for mid-infrared sensing and chemical imaging [9200-57]

\section{POSTER SESSION}

920011 Recent advance in application of acousto-optic tunable filters [9200-14]

920012 Design of equiangular spiral photonic crystal fiber for supercontinuum generation at 1550 nm [9200-16]

920013 Self-tuning acousto-optic deflectors with acoustic line made of $\left.\mathrm{NaBi}_{(\mathrm{MoO}}\right)_{2}$ crystal [9200-35]

920014 Enhanced stability of Bi-doped $\mathrm{Ge}_{2} \mathrm{Sb}_{2} \mathrm{Te}_{5}$ amorphous films [9200-36]

920015 Error angle determination of the star sensor with liquid cooling [9200-37]

920016 Theoretical for astigmatism Fourier transform-based imaging processor [9200-38]

920017 Dispersion properties of a one-dimensional aperiodic OmniGuide structure [9200-39]

920018 Absorption characteristic and two-center holographic recording in $\mathrm{LiNbO}_{3}: \mathrm{Ce}: \mathrm{Ru}$ crystals [9200-40] 
920019 Organic photovoltaic cells of fully conjugated poly[2,6- (4,4-bis(2-ethylhexyl)-4Hcyclopenta[2,1-b;3,4-b']dithiophene)-alt-4,7-(2,1,3-benzothiadiazole)] doped with fullerene [9200-41]

92001 A Thermal effect of organic photovoltaic cells of fully conjugated poly-(3-hexylthiophene) doped with derivatized fullerene [9200-42]

9200 1B DLC thin films influence the thermal dissipation of LED lights [9200-43]

$92001 \mathrm{C}$ Optimized design of $\mathrm{Yb}^{3+} / \mathrm{Er}^{3+}$-codoped cross-coupled integrated microring resonator arrays [9200-44]

9200 ID Characterization of long-period fiber grating as load sensing [9200-45]

9200 IF Mechanically induced long-period gratings in polarization maintaining photonic crystal fiber with a supercontinuum generation source [9200-47]

9200 IG Photoconductivity of ZnO based granular structures [9200-48]

$92001 \mathrm{H}$ Design of the binary-encoded fringe pattern for projected fringe profilometry [9200-49]

$920011 \quad$ Projected fringe profilometry for non-diffusive objects [9200-50]

$9200 \mathrm{lJ}$ 3D shape measurements for plano-convex lenses using fringe projection techniques [9200-51]

$92001 \mathrm{~K}$ A scanning approach using fringe projection techniques for 3D profile measurements [9200-52]

$92001 \mathrm{~L}$ Vibrometry analysis of electrooptical coupling near piezoelectric resonance [9200-53]

$92001 \mathrm{M}$ Homodyne and heterodyne optical interferometry for frequency dependent piezoelectric displacement measurement [9200-54]

$92001 \mathrm{~N}$ Ponderomotive force induced nonlinear interaction between terahertz wave and air plasmas [9200-55] 
Prikhodko, O., 14

Prokashev, Vadim N., 11

Qi, Xiaohua, 18

Rahman, Md. Shafiqur, OA

Ramos-Ortiz, G., OL

Rani, Preeti, $0 Q$

Razzhivalov, P., 15

Reshetnyak, V. Yu., OV

Ritchie, Grant, 10

Rocha Garcia, Pedro Pablo, 17

Rojas-Laguna, R., 1D, IF

Ruffin, Paul, OU

Saini, T. S., $\mathrm{OH}, \mathrm{OS}, 12$

Sarkisov, Sergey, OC

Selvas-Aguilar, R., OD

Shakin, Oleg $V_{.}, 11,13$

Shih, Wen-Tse, 09

Shulika, Oleksiy V., OL

Shyu, Feng Lin, 1B

Sierra-Hernández, J. M., 1D

Sinha, R. K., OH, OQ, OS, 12

Su, Wei-Hung, 1H, 1I, 1J, 1K

Sukhoivanov, Igor A., OL, 17

Sun, Jianfeng, 16

Tabiryan, N. V., OV

Taylor, Keylantra, OC

Timoshenkov, S., 14, 15

Toral-Acosta, D., OD

Trejo-Duran, M., IF

Trofimov, Vyacheslav A., 04

Tsendin, K., 14

Tsypkin, A. N., OW

Tuz, Vladimir R., 17

Vaganov, Mikhail A., 11, 13

Vallés, Juan A., 1C

Vargas-Rodríguez, E., 1D, IF

Walker, Vernell, OC

Wang, Chao, 00

Wang, K. W., OK

Wang, Ying, IN

Wang, Zheng, ON

Yao, Jim, 00

Yin, Stuart Shizhuo, 00, 0U, 0X, IN

Yu, Y. H., OK

Yuan, Chengxun, 1N

Zghal, M., OS, 12

Zhang, Hao, ON

Zhdanov, Arseniy Yu., 11, 13

Zhi, Ya'nan, 16, 18

Zhu, Wenbin, OX

Zou, Jun, 00 


\section{Conference Committee}

Program Track and Conference Chairs

Shizhuo Yin, The Pennsylvania State University (United States)

Ruyan Guo, The University of Texas at San Antonio (United States)

Honorary Conference Chair

Francis T. S. Yu, The Pennsylvania State University (United States)

Conference Program Committee

Partha P. Banerjee, University of Dayton (United States)

Liliana Braescu, Institut National de la Recherche Scientifique (Canada)

Ken-Yuh Hsu, National Chiao Tung University (Taiwan)

Rongqing Hui, The University of Kansas (United States)

Suganda Jutamulia, University of Northern California (United States)

Nickolai V. Kukhtarev, Alabama A\&M University (United States)

Ravindra B. Lal, Alabama A\&M University (United States)

Byoungho Lee, Seoul National University (Korea, Republic of)

Liangcai Cao, Tsinghua University (China)

Sergei F. Lyuksyutov, The University of Akron (United States)

Manmohan D. Aggarwal, Alabama A\&M University (United States)

Paul B. Ruffin, U.S. Army Research, Development and Engineering Command (United States)

Narsingh B. Singh, University of Maryland, Baltimore County

(United States)

Ching-Cherng Sun, National Central University (Taiwan)

Xiang Zhang, University of California, Berkeley (United States)

Session Chairs

1 Advances in Photonic Crystals and Materials I

Abdalla M. Darwish, Dillard University (United States)

Ruyan Guo, The University of Texas at San Antonio (United States)

2 Advances in Photonic Crystals and Materials II

Narsingh B. Singh, University of Maryland, Baltimore County

(United States)

Partha P. Banerjee, University of Dayton (United States) 
3 Innovations in Devices and Applications I

Wei-Hung Su, National Sun Yat-Sen University (Taiwan)

Ching-Cherng Sun, National Central University (Taiwan)

4 Innovations in Devices and Applications II

Paul B. Ruffin, U.S. Army Research, Development and Engineering

Command (United States)

Shizhuo Yin, The Pennsylvania State University (United States) 